How to cite this article:

Hingun, M., \& Mohamed Nizamuddin, R. (2020). Amending section 84 patents Act 1983 to encompass the health flexibilities leverage accorded by article 31 bis Trips agreement. UUM Journal of Legal Studies, 11(2), 1-26. https://doi.org/10.32890/ uumjls.11.2.2020.8052

\title{
AMENDING SECTION 84 PATENTS ACT 1983 TO ENCOMPASS THE HEALTH FLEXIBILITIES LEVERAGE ACCORDED BY ARTICLE 31BIS TRIPS AGREEMENT
}

\author{
${ }^{1}$ Mohsin Hingun \& Rahamatthunnisa Mohamed Nizamuddin \\ Ahmad Ibrahim Kulliyah of Law \\ International Islamic University of Malaysia, Gombak, Malaysia
}

${ }^{1}$ Corresponding author: mohsin@iium.edu.my

Received: 13/1/J2020 Revised: 20/4/2020 Accepted: 22/4/2020 Published: 31/7/2020

\begin{abstract}
The significance of this study lies in its proposal to insert an appropriate provision into the Patents Act 1983 to embody the provisions of Article 31bis TRIPS Agreement. The methodology adopted in this study is library-based, and relies extensively on primary sources such as the Paris Convention, the TRIPS Agreement and the Patents Act 1983. This is further supported through secondary sources such as articles, books, websites and newspaper reports. The research question posed in this study aims to identify the most appropriate provision that should be incorporated into the Patents Act 1983 in addressing the public health flexibilities provided under Article 31bis. The purpose of this study is to demonstrate that Article 31bis is best incorporated into the Patents Act 1983, under the right of the government mechanism rather than through the compulsory license mechanism. Furthermore, the scope of this study is limited to issues that address the abuse of monopoly, granted by the patent system, with respect to the dire needs of public health. Hence, this paper discusses the mechanisms that address the abuse of the patent system under Article 5(A) Paris Convention, Articles 31 and 31bis
\end{abstract}


TRIPS Agreement, the relevant corresponding provisions under the Patents Act 1983, and subsequently formulates new proposed amendments to Section 84 of the Patents Act 1983 to buttress the public health flexibilities provided under Article 31bis. The outcome of this study proposes that the provisions of Article 31bis should be incorporated into the Patents Act 1983 under the right of the government mechanism, by replacing the current Section 84 of the Patents Act 1983 with a newly proposed Section 84. 9-7

Keywords: Article 31bis, compulsory licence (CL), Patents Act 1983 (PA), rights of government (ROG), TRIPS Agreement.

\section{INTRODUCTION}

According to Ricketson (1984) $)^{1}$, a patent is the monopolistic right bestowed upon the owner, to exploit his patented invention for a particular duration of time. The law of patent grants the owner of an invention, exclusive rights to the invention, by issuing a patent. Generally, the patent system is designed to stimulate innovation by granting protection, for a certain period of time to the patentee, to monopolize the exploitation of the patented invention exclusively, without any competition from the same or similar invention in the market. Moreover, this system is beneficial to everyone because the law dictates the disclosure of information in exchange for the grant of the patent. This helps spread the technical knowledge for the betterment of all (Bainbridge, 2012, p. 394)2. All members of the Paris Convention for the Protection of Industrial Property $1883^{3}$ (Paris Convention) and the Agreement on Trade-Related Aspects of Intellectual Property Rights $1994^{4}$ (TRIPS Agreement) are obliged to provide a patent regime in their domestic intellectual property

\footnotetext{
Ricketson, S. (1984). The law of intellectual property. Sydney: The Law Book Company Limited.

2 Bainbridge, I. David. (2012). Intellectual property ( $9^{\text {th }}$ ed.) Pearson Education Limited.

3 Paris Convention for the Protection of Industrial Property 1883 (as amended on September 28, 1979), entered into force on June 3, 1984.

4 Agreement on Trade-Related Aspects of Intellectual Property Rights 1994 came into effect on 1 January 1995. Malaysia has been a member of this Agreement since 1 January 1995.
} 
protection mechanism. Malaysia is a member of both the Paris Convention and the TRIPS Agreement. In Malaysia, patent rights are governed by the Patents Act $1983^{5}$ (PA). The PA grants exclusive rights to the owners of the patent with respect to their inventions (Section 36 PA, 1983).

Although the TRIPS Agreement stresses the obligation of members to protect intellectual property rights, it also stipulates that member countries should establish well-balanced guidelines that protect these rights so as to combat any abuse arising from the intellectual property rights, particularly when there is a necessity to protect issues relating to public health and nutrition (Article 8, TRIPS Agreement, 1994). In adhering to good policy, law and governance, particularly with regards to patents, member countries must take aggressive steps to ensure a good balance of rights between patent owners as well as the advancement of public interest and national development goals (Azam, 2016, p.92) ${ }^{6}$. The most common approach governments employ to balance these rights is by introducing exemptions or exclusions to patent rights in their relevant intellectual property laws (Bagley, 2018, pp. 2480-2481) 7 . Another common method employed to balance these rights is through the implementation of compulsory licenses (CL). CL is a legal measure adopted by many governments against patent abuse, particularly in relation to public health crisis (Kyung-Bok, 2019) ${ }^{8}$. It is a legal measure because this mechanism is approved under Article 5(A) of the Paris Convention, and Articles 31 and 31 bis of the TRIPS Agreement. CL is a crucial mechanism when dealing with health-sensitive issues surrounding the patent law (Armouti, 2018, p.383) ${ }^{9}$. Of particular interest

5 Patents Act 1983, (Act 291), enforced October 1, 1986.

6 Azam, M. (2016). The experiences of TRIPS-compliant patent law reform in Brazil, China, India and South Africa-Lessons for Bangladesh. In Intellectual property and public health in the developing world, 89148, Cambridge, UK: Open Book. Retrieved from http://www.jstor.org/ stable/j.ctt1d41dm1.10

7 Bagley, M.A. (2018). The morality of compulsory licensing as an access to medicines tool. Minnesota Law Review, 102(6), 2463-2496.

8 Kyung-Bok Son. (2019). Importance of intellectual property system in attempting compulsory licensing of pharmaceuticals: A cross-sectional analysis. BMC, Globalization and Health, 15, 42. Retrieved October 08, 2019 from MEDLINE Complete Database. https://doi.org/10.1186/ s12992-019-0485-7

9 Armouti, W. (2018). Grounds for compulsory licence with selected cases granted for pharmaceuticals. Tulane Journal of International and 
is the Doha Declaration 2001 (currently known as Article 31bis TRIPS Agreement) that addresses the concern of the World Trade Organization (WTO) members, particularly the least developed countries (LDC), with regards to the supply and easy access to medicines.

This study addresses the issues of the CL- embedded Article 31 bis regarding public health flexibilities and recommends the most suitable provision that is required to be inserted into PA, to improve the leverage on public health flexibilities. Although the Paris Convention and the TRIPS Agreement use the terminology CL to address the "legal infringement" issues dealt therein, in Malaysia CL is categorized into two different rights that are exercised by two different parties. The first category of CL is the right available under Part X of the PA, for application by any person in certain circumstances, whereby this application is processed by the statutory body in charge of intellectual property in Malaysia, i.e. the Intellectual Property Corporation of Malaysia ${ }^{10}$ (MyIPO). Rights of Government (ROG) under Section 84 PA is the second category of CL, where this right is usually invoked by the Government on grounds of national emergency, without the need for an application by any party. These 2 provisions under the PA incorporate the relevant requirements under Article 5(A) of the Paris Convention and Article 31 of the TRIPS Agreement. However, the PA has not incorporated the provisions of the new Article 31 bis of the TRIPS Agreement, which came into effect in January 2017.

This study analyses the balance of rights between patents and public interest by examining the compulsory licensing mechanism envisaged under Article 5(A) of the Paris Convention, and Articles 31 and 31 bis of the TRIPS Agreement. Thereafter, the findings will be cross- referenced to the corresponding provisions in the PA, and ultimately identify the provisions in the PA that are most suitable to be incorporated into the new provisions of Article 31 bis, in relation to public health flexibilities. This study will review the two different mechanisms provided under the PA and with the

Comparative Law, 26(2), 381-404.

${ }^{10}$ Intellectual Property Corporation of Malaysia is a statutory body looking after intellectual property matters in Malaysia which was incorporated under the Intellectual Property Corporation of Malaysia Act 2002, (Act 617), an Act which was enforced on March 3, 2003. 
flexibilities provided under this Article which allow for the right of "legal infringement" on grounds of public health, will subsequently be vested with the Government under the ROG provision through the replacement of the current Section 84 of the PA with a newly proposed Section 84.

\section{METHODOLOGY}

This research adopts the doctrinal legal research methodology. The research methodology is purely library-based, and is mainly reliant on primary sources of information such as the Paris Convention, TRIPS Agreement and the PA. This is further supported by secondary sources, namely textbooks, journals and websites of relevant authorities. The websites of certain authorities are important as the provisions of Article 31 bis had stemmed from a string of events under the purview of such authorities, and therefore had been widely reported. The research is theoretical, analytical and exploratory; where Article 5(A) of the Paris Convention, and Articles 31 and $31 b i s$ of the TRIPS Agreement are analysed and scrutinized, and thereafter, cross-referenced to the PA. This study explores the suitability of Article31bis in relation to the PA and concludes that Malaysia should amend the ROG provision, i.e. Section 84 of the PA to incorporate the public health flexibilities provided under Article 31 bis by proposing an amended draft of a new Section 84 for the PA.

\section{DISCUSSION}

National policies on patents are often long-term policies that take into consideration various strategies that are based on economic, scientific and technological developments (Miyamoto, 2008, p.155) ${ }^{11}$. These policies are significantly important to public interest

considerations which are based on normative, constitutional and

11 Miyamoto, T.(2008). International treaties and patent laws harmonization: today and beyond. Takenaka, T. (Ed.), Patent law: A handbook of contemporary research, (154-187). Cheltenham,UK: Edward Elgar Publishing. Retrieved from https://search-ebscohost-com.ezlib.iium. edu.my $/$ login. aspx $?$ direct $=$ true $\& d b=$ nlebk $\& A N=265871 \&$ site $=$ edslive. 
philosophical justifications (Sitorus, 2016, p. 85) ${ }^{12}$. The issues of public interest are usually issues that are related to the balancing of rights between a patent owner and the public. Article 7 of the TRIPS Agreement requires an international public interest consideration, whereby member countries in ensuring "protection and enforcement of intellectual property, should contribute to the promotion of technological innovation" for the mutual benefits of "producers and users" in a manner that is "conducive to social and economic welfare", and subsequently, to maintain a "balance of rights and obligations". Prior to the TRIPS Agreement, balancing of these rights was first incorporated into the Paris Convention via Article 5(A), whereby the mechanism used to prevent the abuse was expressly referred to therein as CL. The following sections will discuss the various provisions in the Paris Convention and the TRIPS Agreement concerning CL, and we will then make a cross-reference of these provisions to the corresponding provisions in the PA.

\section{Article 5(A) Paris Convention}

Article 5(A) of the Paris Convention which is titled "Patents: Importation of Articles; Failure to Work or Insufficient Working: Compulsory Licenses" allowed members of the Union to incorporate legislative measures into their laws, to prevent abuse of patent rights which may arise due to monopoly rights granted to the patent holders. This can be achieved through the issuance of CL in appropriate cases. An example provided to illustrate such abuse is the failure to work the invention which has been patented (Article 5(A)(2) of the Paris Convention, 1883 (Timble, 2016) ${ }^{13}$. "Failure to work" implies that the owner of an invention that has been granted a patent, had "failed to put into practice" his invention, within the country that issued the patent (Conteras, 2017, p 4) ${ }^{14}$. Article 5(A)

12 Sitorus, W. (2016). Public interest in patent protection: The need of criteria. Journal of Law, Policy and Globalization, 45, 85-94.

13 See Timble, M. (2016). Patent working requirements: Historical and comparative perspectives. UC Irvine Law Review, 6(3), 483-508 for a better understanding on failure to work.

14 Conteras, George L, Rohani Lakshane, Lewis, M. Paxton. ((2017). Patent working requirements and complex products. New York University Journal of Intellectual Property and Entertainment Law, 17, $1-50$. 
stipulates a specific condition in the application of a CL, whereby a CL application will not be entertained on grounds that a patentee has failed to work the invention which had been patented, before the expiration of " 4 years from the date of filing the patent application or 3 years from the date the grant of the patent" was awarded, or whichever period expired last (Article 5(A)(4) Paris Convention, 1883). General terms and conditions to grant CL are also specified therein, however, CL cannot be granted if the owner "justifies his inaction with legitimate reasons", and that the CL will be "nonexclusive and non-transferrable" (Article 5(A)(4) Paris Convention, 1883). There are many countries, for example Bahrain, Brazil, Chile, China and the Philippines (Visser, 2010, p.4) ${ }^{15}$, that have a CL provision in their patent system.

Malaysia, being a signatory of the Paris Convention since January 1, 1989, has incorporated this mechanism of the CL under Part X PA which consists of Sections 48-54. CL, under Part X, is referred to as an authorization to perform in Malaysia, the act of exploiting an invention which has been patented, without the agreement of the patentee (Section 48 PA, 1983). Exploitation includes "making, importing, offering for sale, selling or using the patented product or stocking them for sales" purposes (Section 36(3) PA, 1983). Under the PA, any person can apply for a CL from the Registrar of Patents, in the event that there is "no production of the patented product" in Malaysia, or there is no product for sale in Malaysia, or in some cases, the products are sold at unreasonable high prices without any legitimate reason. The application can only be made after attempts to obtain authorization from the patent owner has been futile (Section 49 PA, 1983), or upon the expiration of the term of 4 or 3 years stated herein above. Although Article 5(A) of the Paris Convention does not specify the procedures with regards to a CL application, Part X of the PA clearly lays down the procedures that are required for the application for a CL, such as the amount of royalty and conditions for exploitation (Section 50 PA, 1983). A CL application

15 Coenrad Visser. (2010). Patent exceptions and limitations in the health context, SCP/15/3 - Experts study on exclusions from patentable subject matter and exceptions and limitations to the rights. World Intellectual Property Organization. SCP/16/REF/SCP/15/3. Annex V. Retrieved October 13, 2019 from https://www.wipo.int/edocs/mdocs/scp/en/ scp_16/scp_16_ref_scp_15_3-annex5.pdf. 
in Malaysia is considered and decided upon by MyIPO. The CL provisions under Part X stems from the provisions of Article 31 of the TRIPS Agreement. Such requirements for $\mathrm{CL}$ are the efforts that are needed to be undertaken to obtain the patentee's approval first, and the grant of CL can only be given for the supply of the patented product into the local market. The requirements in Article 31 herein will be further discussed in the following section.

The concise provisions regarding $\mathrm{CL}$ under Part $\mathrm{X}$ of the PA are solid and comply with Article 5(A) of the Paris Convention, and the decision to grant CL being vested in MyIPO, is indeed the correct approach chosen by the Malaysian Government. MyIPO is the statutory body that is in charge of intellectual property matters and is capable of assessing the reasons to grant a CL to an applicant in accordance to Part X, as the issues involved must be within the Malaysian territory. For this reason, the verification of information about these situations in the event that an issue arises may be easily obtained through investigations carried out by MyIPO. The availability of CL under the PA is important to Malaysia because being a developing country, balancing of rights between the patent owners and the public is indeed of utmost importance (Arega, 2019 , p. 31 ${ }^{16}$. Thus far, there has been no application for a CL to MyIPO. Although issues relating to high prices of medicines had arisen in Malaysia, particularly medication for HIV and Hepatitis C, the provisions of CL under Part X of the PA were never put to use as no third party or generic manufacturers had applied to MyIPO for a CL to combat these rising prices. Therefore, to address these health problems, the Government invoked the ROG as can be seen in the following part. Hence, till today, MyIPO has no experience in dealing with issues in respect of the issuance of CL.

\section{Article 31 TRIPS Agreement}

Article 31 is titled "Other Use without Authorization of the Right Holder". Article 31 allows members to accommodate a provision in their laws allowing the use of an invention which has been patented, without acquiring consent from the patentee. This right was granted mainly to three parties; "a third party", "the government", or "other

16 Arega, M. (2019). Defending local working. American University Intellectual Property Brief, 10(2), 28-61. 
parties that are authorized by the government", where this right is subjected to certain rules ${ }^{17}$. Article 31 is a continuation of Article 30. Article 30 gives an option to member countries "to provide limited exceptions to the exclusive rights conferred by a patent, provided that such exceptions do not unreasonably conflict with the normal exploitation of the patent" in issue (Guan, 2016, pp. 423-424) ${ }^{18}$. Article 31 "gives permission" to third parties to use the invention that has been granted a patent, without the consent of the patentee, for reasons other than those provided under Article 30. Although Article 31 makes no reference to the term CL, it is nevertheless commonly referred to as the "CL provision" (Effingham, 2016, pp. 883-909; Raducanu, 2011; WTO; World Health Organization $[\mathrm{WHO}])^{19}$. This is supported by the stringent rules that need to be

17 An example of such rules is the authorization of the use shall be based on individual merits and there shall be a right of judicial review of such authorization; the use is only authorized should efforts made to obtain the patentee's authorization had been futile. This rule is exempted in situations of national emergency, other circumstances of extreme urgency or in cases of public non-commercial use. Nevertheless, in such cases, the patentee shall be informed of this use as soon as possible.; the scope and duration of the use shall be limited to the purpose it was authorized The use shall be non-exclusive; the use shall be non-assignable; the use shall be predominantly for the supply of the local market only; the use shall be subject to adequate protection of the legitimate interest of the party so given the authorization and such authorization can be terminated when the reason for the authorization given, had ceased. The patentee is paid adequate remuneration for the use and issues related to adequacy shall be subject to judicial review; and for purposes of remedying a practice determined as anti-competitive. The use need not be subjected to the rule of obtaining the approval of the patentee first and the rule to supply for the domestic market only.

18 Guan, W. (2016). IPRs, public health, and international trade: An international law perspective on the TRIPS amendment. Leiden Journal of International Law, 29(2), 411-440. An example of an exception to patent right is that rights of patents are only for commercial purposes and do not cover acts done solely for scientific purpose. This limitation of right is provided under the PA in Section 37.

19 Effingham, Ann Marie. (2016). TRIPS Agreement Article 31(b): The need for revision. Seton Hall Law Review, 46, no.3, 883-909; Raducanu, Adina.(2011). Who is afraid of compulsory licences. USAK Yearbook of International Policy \& Law, 4, 255-288; World Trade Organization. (n.d.). Compulsory licensing of pharmaceuticals and TRIPS. Retrieved 
adhered to which are listed out therein when exercising this right of "legal infringement". Article 31 is not a mandatory provision as it offers member countries the choice to adopt and establish this system.

Malaysia, being a signatory to the TRIPS Agreement since 1995, has opted to use this system and has incorporated the provisions into the PA. Most of the rules and provisions stated in Article 31 have been incorporated into Part X PA. Hence, Part X consists of a combination of Article 5(A) of the Paris Convention and Article 31 of the TRIPS Agreement (only to the extent where this system is used by a third party). Subsequently, when "a Government or a party authorized by the Government" uses this system, the PA defines this utilization as the "Rights of Government", which has been specifically incorporated into Section 84 . The PA clearly distinguishes CL from ROG. CL is applied by a third party strictly on grounds that are specified under Article 5(A) of the Paris Convention and under Part X of the PA, whereas ROG is invoked by the Government for the application of the system by "the Government or a third party that is authorized by the Government" on two specific grounds. Firstly, ROG is invoked in the event of "national emergency" or "public interest", such as "national security and health" issues (Article 31(b)). Secondly, it is granted when "a judicial or relevant authority has determined" that the patent owner had exploited his invention in an "anti-competitive" manner, (Article 31(c)). Although Article 31 does not distinguish between CL and ROG, the PA has demarcated these rights into two categories of rights that are used by different parties. This allows for a much simpler and clearer determination of rights to ensure an appropriate balance of rights between patent owners and the public ${ }^{20}$. Issues involving abuse of patent rights within the local territory is governed by MyIPO, while matters involving national interests are regulated by the Government. The ROG, under Section 84 of the PA, can only be invoked by the Minister of Domestic Trade and

July 22, 2019, from https://www.wto.org/english/tratop_e/trips_e/ public_health_faq_e.htm; and World Health Organization. (n.d). The Doha Declaration on the TRIPS Agreement and public health. Retrieved July 22, 2019, from https://www.who.int/medicines/areas/policy/policy/doha_declaration/en/.

20 See Ali, F. (2016). Nexavar: The first market-initiated compulsory licence. NUJS Law Review, 9(2), 229-258, for further understanding on difference between a government use CL (ROG in Malaysia) and market-initiated CL (CL in Malaysia). 
Consumer Affairs (DTCA), as the ministry is in charge of matters relating to intellectual property, upon determination by the Cabinet, i.e. the Government, on either of the events specified above (Section 84(1) PA). Moreover, until such a determination has been made by the Government, the Minister of DTCA has no right to invoke the ROG.

Malaysia has invoked the ROG mechanism twice, initially in 2004 to address the HIV issue, and once again in 2017 to address the Hepatitis $\mathrm{C}$ issue in Malaysia. However, the invocation of this right under ROG was commonly mistaken to be an issuance of $\mathrm{CL}^{21}$. Taking into account the 2 different mechanisms of $\mathrm{CL}$ and ROG that exist under the PA, this study focuses on clarifying this misconception and then goes on to suggest the incorporation of Article 31 bis of the TRIPS Agreement into the PA by the inserting a new proposed Section 84 PA. The detailed substantive provisions on ROG as envisaged under the current Section 84 of the PA are rigorous and fit the purpose of Articles 31(b) and 31(c) of the TRIPS Agreement. The decision to place the invocation of ROG under the purview of the Government has indeed been the correct approach chosen by the Malaysian Government. The Minister of DTCA is in a strong and capable position to deal with the implications of a national emergency and public interest situation as he is part of the Cabinet and is able to understand the situation comprehensively (Ahmad, 2012) $)^{22}$. As the Minister is in charge of intellectual property matters under the current legal system, he will be able to exercise his rights accordingly under the PA by taking into account the national agenda.

21 See Foley, E. (2019). Predicting the 2019301 Special Report. Creighton International and Comparative Law Journal, 10(1), 87-101; Third World Network. (2017, November 3). Sharing national experiences in use of compulsory licences. Retrieved September 10, 2019, from https://www.twn.my/title2/intellectual property/info.service/2017/ ip171102.htm; and Report: Cabinet approves compulsory licence for Hepatitis C generics. (2017, September 14). The Malay Mail. Retrieved September 10, 2019, from https://www.malaymail.com/news/ malaysia/2017/09/14/report-cabinet-approves-compulsory-license-forhepatitis-c-generics/1464619.

22 Ahmad Masum. (2012). The doctrine of ministerial responsibility in Malaysia: Theory and practice in a new regime of parliamentary accountability. Malayan Law Journal Article, 4, clv-clxxvi. 


\section{Article 31bis TRIPS Agreement}

Article 31 bis is the newly inserted provision of the TRIPS Agreement, which was enforced in January 2017. It embodies the effort of the members of the WTO in recognising the need of a system to help the poorer member countries to gain easier access to medicine (Alsegard, 2004) ${ }^{23}$. Article $31 \mathrm{bis}$ clearly refers to the system envisaged therein as CL and provides flexibility to "countries with insufficient or inexistent manufacturing capabilities" to produce the pharmaceutical products which have been granted patents, without first obtaining the permission of the patentee, and this can be done strictly on reasons of public health flexibilities. Member countries of the WTO finally recognized this concern, particularly the need of those in the least developed countries (LDC) to have access to medicines through imports from other countries (WTO) ${ }^{24}$. The LDC lack the manufacturing capabilities, and therefore, these countries are not able to produce medicines to cater for their public health concern. Consequently, Article 31 bis was introduced to allow CL to be invoked, whereby generic medicines can be made and there is no need to obtain authorization from the patentee to do this. The generic versions are then exported by the exporting member country to the LDC which are the eligible importing countries (Houston, 2019, pp. 232-233) $)^{25}$. This is the main objective of Article 31 bis. Many countries such as Canada, Norway and Netherlands have begun amending their patent legislation since the Doha Declaration 2003 (Abbot \& Van Pyumbroeck, 2005, pp. 2-3) ${ }^{26}$ which embodies

23 Alsegard, Erik. (2004). Global pharmaceutical patents after the Doha Declaration - What lies in the future. SCRIPTed: A Journal of Law, Technology and Society, 12, 12-45.

24 World Trade Organization (n.d). TRIPS and public health. Retrieved July 22, 2019, from https://www.wto.org/english/tratop_e/trips_e / pharmpatent_e.htm.

25 Houston, A. R., \& Beall, R. F (2018). Could the paragraph compulsory licence system be revised to increase participation by the generics industry: Lessons learned from unheralded and unsuccessful attempt to use Canada's access to medicines regime. McGill Journal of Law and Health, 12, 227-246.

26 Abbot, F. M., \& Van Pyumbroeck, R.V.(2005). Compulsory licensing for public health A guide and model documents for implementation of the Doha Declaration Paragraph 6 decision. World Bank Working Paper No. 61. Retrieved from http://documents.worldbank.org/curated/ en/173701468337882214/pdf/334260rev0pub.pdf. 
the decision of Paragraph 6 therein, and has now been incorporated into Article 31 bis.

It is indeed disheartening to note that as of 2019, the PA does not have a provision on the public health flexibilities provided by Article 31bis despite Malaysia being involved in "the Doha Declaration on TRIPS and Public Health" since 2001. Malaysia also accepted the "Protocol Amending the TRIPS Agreement" in December 2015 (WTO). It has been more than 2 years since this Protocol was enforced, however, Malaysia is yet to incorporate these flexibilities into the PA. As a developing country, Malaysia must address the global call on affordable access to medicines. As far as Malaysia is concerned, this call envisaged under Article 5(A) of the Paris Convention and Article 31 of the TRIPS Agreement has been implemented by incorporating the provisions on CL and ROG into the PA. However, the policy, law and governance in managing the country, especially with regards to public health concerns, must be expanded to benefit the less fortunate countries, particularly the LDC, through the integration of the provisions of Article 31 bis into the PA.

\section{RECOMMENDATIONS}

Whilst the patent system's integrity must be enforced accordingly, it is simply just right for the public to have access to affordable medications, particularly in times of crisis involving public health (Halterman, 2018, p. 511) 27. Therefore, this study proposes that Malaysia incorporates the provisions of Article 31 bis into the PA by amending Section 84 to grant the Malaysian Government the right to expand the benefit it has provided to its citizens and to include the citizens of other lower income countries. Furthermore, the implementation of this mechanism will ensure adequate remuneration to the patent owner and provide assurances that the right will be exercised prudently and meticulously by the sovereignty of the country, based on the given situation. Invocation of the ROG would be the most appropriate mechanism to be adopted by Malaysia for

27 Halterman, C. (2018). Patent rights v public access: Interpreting the public interest factor in pharmaceutical patent infringement cases. Southern Illinois University Law Journal, 42(3), 499-520. 
purposes of Article 31bis, as the Government is in the best position to monitor recent developments within the global community. In addition, the ability of the Government to assess the need of other sovereign countries, in relation to the access of medicines, would eliminate any potential abuse of the public health flexibilities as cautioned under paragraph (4) Annex to Article 31bis.

A CL system under Part X would be inappropriate in such scenarios as the time and costs may be significantly expended, particularly since it is a pre-condition that a person seeking a CL must have first taken steps to ensure that he has attempted to obtain the consent of the patentee. This action alone will take time and would lead to unnecessary delays in putting into effect the main aim of Article 31 bis. In addition, there is a possibility that the documents involved in the implementation of Article 31bis may require authentication. MyIPO, being the statutory body in charge of CL in Malaysia, may need verification from the Government on the authenticity of the documents submitted, and this may take more time. This was observed when Canada had access to the medicine regime through the CL system and was corresponding with the Canadian Intellectual Property Office in handling the application. However, it took 15 months before supply could be given to Rwanda during the crisis in 2007 due to the long processing time (Anderson, 2010, p. 180) ${ }^{28}$. This suggests that a CL system is an inappropriate system for the purposes of Article 31bis. Many African countries such as Namibia, Zanzibar and Botswana have incorporated this system into their legislations, whereby this right lies with their Ministers (Banda, 2016, p. 71) ${ }^{29}$. Envisaging the rights under Article 31bis at the Ministerial levels would be the most appropriate measure to address the issues related to Article 31bis. Essentially, when a sovereign country uses this right, it captures the attention of the international community, hence, ensuring a good monitoring system of use under Article 31 bis.

28 Anderson, B. (2010). Better access to medicines. Why countries are getting tripped up and not ratifying Article 31-bis. Case Western Reserve Journal of Law, Technology and the Internet, 1(2), 165-182.

29 Banda, C. (2016). Intellectual property and access to essential pharmaceuticals: Recent law and policy reforms in the Southern Africa development community region. Maryland Journal of International Law, 31, 44-78. 
Based on the above reasons, in order to ensure the elimination of abusive practices of the system under Article $31 \mathrm{bis}$, this study proposes that the right to invoke this system should be placed under the purview of the Malaysian Government as a ROG pursuant to Section 84 of the PA, and not under the CL system pursuant to Part X of the PA. Furthermore, this study suggests substituting the existing Section 84 of the PA, with a new Section 84, whereby the current provision on ROG pursuant to Article 31 of the TRIPS Agreement is expanded to include the flexibilities provided under Article $31 \mathrm{bis}$. The new proposed Section 84 is set out here below where only the amended provisions are shown without much repetition of the existing provisions. The current existing Section 84 of the PA is reproduced in the Appendix, for ease of comparison and identification of the relevant amendments proposed to be made thereto.

"Section 84. Rights of Government.

(1) Notwithstanding ......-

(a)

(b) $\quad \ldots \ldots \ldots \ldots \ldots \ldots$;

(c) where there is a request made by an eligible importing country, to the Government for the manufacture of a pharmaceutical product to address an epidemic issue in its country, and the Government agrees to such a request; or

(d) where there is an epidemic problem in respect of public health in Malaysia and the Government decides to import a pharmaceutical product from an exporting country, to address this problem,

(3) Where invocation of the rights by the Minister is pursuant to: -

(a) paragraph (1)(c), the Government shall notify the Council for TRIPS of all relevant information regarding the exportation of the pharmaceutical product; and 
(b) paragraph (1)(d), the Government shall notify the Council for TRIPS of all relevant information regarding the importation of the pharmaceutical product.

(4) The exploitation of the patent under this section shall be limited to the purpose for which it was authorized and shall be subject to payment to the owner of the patent of an adequate remuneration for such exploitation, taking into account:

(a) the economic value of the Minister's authorization as determined in the decisions under paragraphs $1(a)$ and $1(d)$;

(b) where a decision has been taken under paragraph (1)(b), the need to correct anticompetitive practices; and

(c) where a decision has been taken under paragraph (1)(c), the economic value to the eligible importing country of the use that has been authorized by the Minister.

(5) Notwithstanding subsection (4), in the event the Minister's authorization under this section is pursuant to paragraph (1)(d), the Minister shall not be required to pay any remuneration to the owner of the pharmaceutical product in Malaysia, in the event the owner of the pharmaceutical product had been paid remuneration in the exporting country.

(6) The Minister shall make his decision under subsection (4) after hearing the owner of the patent and any other interested person, if they wish to be heard. (the current subsection (5)). 
(8) . (the current subsection (6)).

(9) (the current subsection (7)).

(10) Theexploitationof thepatent bythe Government agency or the third person designated by the Minister shall be predominantly for the supply of the market in Malaysia:

Provided always that this paragraph shall not be applicable in the event the exploitation by the Government agency or the third person designated by the Minister, is made pursuant to an authorization issued in accordance with paragraph (1)(c).

(11) Upon the request of:-

(a) the owner of the patent;

(b) the Government agency or the third person authorized to exploit the patent; or

(c) the eligible importing country,

the Minister may, after hearing the relevant parties, if they wish to be heard, vary the terms of the decision authorizing the exploitation of the patent, to the extent that the changed circumstances justify such variation, provided always that, for changes involving a situation which concerns paragraph (c) of subsection (1), the Government shall notify the Council for TRIPS, of such changes. (the current subsection 10)).

(13) Notwithstanding subsection (12), the Minister shall not terminate the authorization if he is satisfied that the need for adequate protection of the legitimate interests of the Government 
agency or the third person designated by him justifies the maintenance of the decision.

(14) ..... (the current subsection (12).

(15) In this section-

"Council for TRIPS" means the body responsible for administering the TRIPS Agreement under the World Trade Organization;

"eligible importing country" means any least-developed country or any other member country of the TRIPS Agreement that has made a notification to the Council for TRIPS of its intention to make a request to import a pharmaceutical product, in accordance with Article 31bis and Annex of the TRIPS Agreement;

"exporting country" means a TRIPS Agreement member country which produces pharmaceutical products for and exports them, to Malaysia;

"Government agency" means the Federal Government or the Government of a State and includes a Ministry or Department of that Government;

"patented invention" means any invention that has been patented in accordance with this Act and includes pharmaceutical products;

"pharmaceutical product" means any patented product, or product manufactured through a patented process, of the pharmaceutical sector including but not limited to the active 
ingredients necessary for its manufacture and diagnostic kits needed for its use, which is required to address an epidemic problem;

\section{"TRIPS Agreement" means the Agreement on Trade-Related Aspects of Intellectual Property enforced on January 1, 1995 including any amendments thereto."}

The proposed amendments embodied in the above new Section 84 of the PA will grant the Government various flexibilities in invoking the provisions of Article 31 and Article 31 bis, under a single provision in the PA.

\section{CONCLUSION}

Malaysia is indeed a TRIPS compliant member country and has set up a good legal protection mechanism for the enforcement of intellectual property rights. Although Malaysia highly respects and encourages the security of intellectual property, it has always attempted to strike a fair balance between the intellectual property rights owner and the wider interest of the public, particularly in respect of the law relating to patents. This requirement of balance for patent rights is enshrined in Article 5(A) of the Paris Convention and Articles 31 and 31bis of the TRIPS Agreement. These provisions allow governments to exercise some flexibilities, should there be abuse of patent rights. It is a human's right to have a right to healthcare, and there is no doubt that having easy access to medicines is also an embodied right. Malaysia garnered international attention when it provided easy access to medicines to Malaysians when the country was faced with public health problems in 2004 and 2017, signifying Malaysia's approach to the balance of rights while protecting intellectual property rights through the invocation of the ROG mechanism pursuant to Section 84 of the PA. Malaysia should fully endorse the new Article 31 bis, particularly for supporting the LDC, by incorporating a provision into the PA to address the issue therein.

The incorporation of this Article into Section 84 of the PA under the ROG mechanism, would uphold the Government's sovereign 
position and concern towards public health issues, in the eyes of the world, since it is the Government itself that will be handling this issue directly and not merely an agency of the Government (MyIPO). It is proposed that the flexibilities under Article 31bis of the TRIPS Agreement be carried out via the ROG mechanism under Section 84 of the PA, and not the CL mechanism under Part $\mathrm{X}$ of the PA, because it shows the Government's sovereign handson approach when dealing with public health issues concerning its citizens and its country, as well as the rest of the world. In addition, the current Article 31 of the TRIPS Agreement provisions in respect of interference of patents on grounds of security and public health issues for use in domestic situations, are already embedded in the ROG mechanism under Section 84 of the PA. Therefore, it is simply prudent and logical that for purposes of Article 31bis (incorporated into the TRIPS Agreement pursuant to the provisions of Article 31 specially to address issues relating to public health crisis only, which includes the right of the country to now export the pharmaceutical products for use outside its country), these rights be inserted into the ROG mechanism under Section 84 of the PA and not the CL mechanism under Part X of the PA.

Suggestions of incorporating the flexibilities provided under Article 31 bis of the TRIPS Agreement into Part X of the PA (if any), would set a double standard in the Government's approach towards public health crisis, whereby for issues of public health in its country, the sovereign decides, but for the public health crisis in other countries, a mere organization in charge of intellectual property viz. MyIPO would be the decision- maker. This double standard would not make Malaysia look good in the eyes of the world as Malaysia has always been recognized by the world as a champion for its efforts with regards to public health matters, both nationally and internationally. This great concern of "always being there and playing an important role during a public crisis situation" shown by Malaysia, can be evidenced based on Malaysia's public health- related actions taken in 2004 and 2017 and more so important, now, in 2020, where Malaysia is playing an active role by implementing hands-on actions in addressing the current Covid-19 pandemic, when it was one of the first few countries in the world to implement the "lockdown" mechanism, by introducing the Movement Control Order in its effort of curbing the pandemic. Malaysia's actions which are being 
carried out gracefully and calmly, is not only for the benefit of the Malaysians themselves but also for the benefit of the world at large.

This shows that Malaysia places utmost importance on issues relating to public health and as such, for purposes of Article $31 \mathrm{bis}$ of the TRIPS Agreement, the most appropriate mechanism is the ROG mechanism, which allows the Government of Malaysia to exercise the public health flexibilities and not the CL mechanism under the purview of an agency viz. MyIPO. Both the world at large, particularly the LDC, as well as Malaysians, stand to benefit from this proposal of envisaging Article 31bis of the TRIPS Agreement into Section 84 of the PA, as it is the sovereign of the state with access to all information in hand, that will immediately decide on a public health crisis, whether be it a crisis at the national or international level.

\section{REFERENCES}

Abbot, F. M., \& Van Pyumbroeck, R. V. (2005). Compulsory licensing for public health A guide and model documents for implementation of the DohaDeclaration Paragraph 6 decision. World Bank Working Paper No. 61. Retrieved from http:// documents.worldbank.org/curated/en/173701468337882214/ pdf/334260rev0pub.pdf.

Agreement on Trade-Related Aspects of Intellectual Property Rights. (1994).

Ahmad Masum. (2012). The doctrine of ministerial responsibility in Malaysia: Theory and practice in a new regime of parliamentary accountability. Malayan Law Journal Article, 4, clv-clxxvi.

Ali, F. (2016). Nexavar: The first market-initiated compulsory licence. NUJS Law Review, 9(2), 229-258.

Alsegard, Erik. (2004). Global pharmaceutical patents after the Doha Declaration - What lies in the future. SCRIPTed: A Journal of Law, Technology and Society, 12, 12-45.

Anderson, B. (2010). Better access to medicines. Why countries are getting tripped up and not ratifying Article 31-bis. Case Western Reserve Journal of Law, Technology and the Internet, 1(2), 165-182. 
Arega, M. (2019) Defending local working. American University Intellectual Property Brief, 10(2), 28-61.

Armouti, W. (2018). Grounds for compulsory licence with selected cases granted for pharmaceuticals. Tulane Journal of International and Comparative Law, 26(2), 381-404.

Azam, M. (2016). The experiences of TRIPS-compliant patent law reform in Brazil, China, India and South AfricaLessons for Bangladesh. In Intellectual Property and Public Health in the Developing World (pp. 89-148). Cambridge, UK: Open Book. Retrieved from http://www.jstor.org/stable/j.ctt1d41dm1.10.

Bagley, M. A. (2018). The morality of compulsory licensing as an access to medicines tool. Minnesota Law Review, 102(6), 2463-2496

Bainbridge, I., David. (2012). Intellectual property. ( $9^{\text {th }}$ ed.). Pearson Education Limited.

Banda, C. (2016). Intellectual property and access to essential pharmaceuticals: Recent law and policy reforms in the Southern Africa development community region. Maryland Journal of International Law, 31, 44-78.

Coenrad Visser. (2010). Patent exceptions and limitations in the health context, SCP/15/3 - Experts study on exclusions from patentable subject matter and exceptions and limitations to the rights. World Intellectual Property Organization. SCP/16/ $\mathrm{REF} / \mathrm{SCP} / 15 / 3$. Annex V. Retrieved October 13, 2019 from https://www.wipo.int/edocs/mdocs/scp/en/scp_16/scp_16_ ref_scp_15_3-annex5.pdf.

Conteras, George L., Rohani Lakshane, Lewis, M., Paxton. ((2017). Patent working requirements and complex products. New York University Journal of Intellectual Property and Entertainment Law, 17, 1-50.

Effingham Ann Marie. (2016). TRIPS Agreement Article 31(b): The need for revision. Seton Hall Law Review, 46, no.3, 883-909.

Foley, E. (2019). Predicting the 2019301 Special Report. Creighton International and Comparative Law Journal, 10(1), 87-101.

Guan, W. (2016). IPRs, public health, and international trade: An international law perspective on the TRIPS amendment. Leiden Journal of International Law, 29(2), 411-440.

Halterman, C. (2018). Patent rights v public access: Interpreting the public interest factor in pharmaceutical patent infringement cases. Southern Illinois University Law Journal, 42(3), 499- 
520.

Intellectual Property Corporation of Malaysia Act 2002. (Act 617). Kyung-Bok Son. (2019). Importance of intellectual property system in attempting compulsory licensing of pharmaceuticals: A cross-sectional analysis. BMC, Globalization and Health, 15, 42. Retrieved from MEDLINE Complete Database https:// doi.org/10.1186/s12992-019-0485-7.

Miyamoto, T. (2008). International treaties and patent laws harmonization: Today and beyond. Takenaka, T. (Ed.), Patent law: A handbook of contemporary research, (154-187). Cheltenham, UK: Edward Elgar Publishing. Retrieved from https://search-ebscohost-com.ezlib.iium.edu.my/login.aspx? direct $=$ true $\& d b=$ nlebk $\& A N=265871 \&$ site $=$ eds-live.

Paris Convention for the Protection of Industrial Property 1883 (as amended on September 28, 1979).

Patents Act 1983, (Act 291).

Raducanu, Adina. (2011). Who is afraid of compulsory licences. USAK Yearbook of International Policy \& Law, 4, 255-288.

Report: Cabinet approves compulsory licence for Hepatitis C generics. (2017, September 14). The Malay Mail. Retrieved from https:/www.malaymail.com/news/malaysia/2017/ 09/14/report-cabinet-approves-compulsory-license-forhepatitis-c-generics/1464619.

Ricketson, S. (1984). The law of intellectual property. Sydney: The Law Book Company Limited.

Sitorus, W. (2016). Public interest in patent protection: The need of criteria. Journal of Law, Policy and Globalization, 45, 85-94.

Third World Network. (2017, November 3). Sharing national experiences in use of Compulsory licences. Retrieved from https://www.twn.my/title2/intellectual_property/_info. service/2017/ip171102.htm.

Timble, M. ((2016). Patent working requirements: Historical and comparative perspectives. UC Irvine Law Review, 6(3), 483508.

World Health Organization. (n.d). The Doha Declaration on the TRIPS Agreement and public health. Retrieved from https://www.who.int/medicines/areas/policy /policy/doha declaration/en/

World Trade Organization. (n.d.). Compulsory licensing of pharmaceuticals and TRIPS. Retrieved from https://www. 
wto.org/english/tratop_e/trips_e/public_health_faq_e.htm.

World Trade Organization. (n.d). TRIPS and public health. Retrieved from https://www.wto.org/english/tratop_e/trips_e /pharmpatent_e.htm.

\section{Appendix}

"Section 84 Patents Act 1983. Rights of Government.

(1) Notwithstanding anything contained in this Act -

(a) where there is national emergency or where the public interest, in particular, national security, nutrition, health or the development of other vital sectors of the national economy as determined by the Government, so requires; or

(b) where a judicial or relevant authority has determined that the manner of exploitation by the owner of the patent or his licensee is anti-competitive, the Minister may decide that, even without the agreement of the owner of the patent, a Government agency or a third person designated by the Minister may exploit a patented invention.

(2) The owner of the patent shall be notified of the decision of the Minister as soon as is reasonably practicable.

(3) The exploitation of the patented invention shall be limited to the purpose for which it was authorized and shall be subject to the payment to the owner of the patent of an adequate remuneration for such exploitation, taking into account -

(a) the economic value of the Minister's authorization as determined in the decision; and

(b) where a decision has been taken under paragraph (1) (b), the need to correct anti-competitive practices.

(4) The Minister shall make his decision under subsection (3) after hearing the owner of the patent and any other interested person if they wished to be heard.

(5) The exploitation of a patented invention in the field of 
semi-conductor technology shall only be authorized either -

(a) for public non-commercial use; or

(b) where a judicial or relevant authority has determined that the manner of exploitation of the patented invention, by the owner of the patent or his licensee, is anticompetitive and if the Minister is satisfied that the authorization would remedy such anti-competitive practice.

(6) The authorization shall not exclude -

(a) the continued exercise by the owner of the patent of his rights under subsection 36(1); or

(b) the issuance of compulsory licences under Part X.

(7) Where a third person has been designated by the Minister, the authorization may only be transferred with the goodwill or business of that person or with that part of the goodwill or business in which the patented invention is being exploited.

(8) The exploitation of the invention by the Government agency or the third person designated by the Minister shall be predominantly for the supply of the market in Malaysia.

(9) Upon the request of -

(a) the owner of the patent; or

(b) the Government agency or the third person authorized to exploit the patented invention,

the Minister may, after hearing the parties, if either or both wish to be heard, vary the terms of the decision authorizing the exploitation of the patented invention to the extent that changed circumstances justify such variation.

(10) Upon the request of the owner of the patent, the Minister shall terminate the authorization if he is satisfied, after hearing the parties, if either or both wish to be heard, that the circumstances mentioned in subsection (1) which led to his decision have ceased to exist and are unlikely to recur or that the Government agency or the third person designated by him has failed to comply with the terms of the decision. 
UUMJLS 11(2), July 2020 (1-26)

(11) Notwithstanding subsection (10), the Minister shall not terminate the authorization if he is satisfied that the need for adequate protection of the legitimate interests of the Government agency or the third person designated by him justifies the maintenance of the decision.

(12) The owner of a patent, a Government agency or the third person authorized to exploit a patented invention may appeal to the Court against the decision of the Minister under this section.

(13) In this section "Government agency" means the Federal Government or the Government of a State and includes a Ministry or Department of that Government." 